\title{
Pearls \& Oy-sters: Contrast-induced encephalopathy following coronary angiography
}

A rare stroke mimic

Yohei Harada, MD, Supriya R. Kairamkonda, MD, Ushna llyas, MD, Naga V.K. Pothineni, MD, Rohan S. Samant, MD, Vishank A. Shah, MD, Nidhi Kapoor, MD, Sanjeeva Onteddu, MD, and Krishna Nalleballe, MD

Neurology ${ }^{\circledR}$ 2020;94:e2491-e2494. doi:10.1212/WNL.0000000000009590

\section{Pearls \& Oy-sters}

The clinical presentation of contrast-induced encephalopathy (CIE) varies widely, including altered mental status, focal motor and sensory deficit, visual disturbance, ophthalmoplegia, global aphasia, and seizures.

Radiologically, CIE can mimic subarachnoid hemorrhage (SAH) on CT head with hyperdensity in the subarachnoid space due to iodinated contrast extravasation.

CIE is a diagnosis of exclusion that requires comprehensive workup and close monitoring of neurologic examination.

\section{Case report}

A 72-year-old woman with history of hypertension and hyperlipidemia presented with chest pain, lightheadedness, and diaphoresis. ECG revealed acute inferior myocardial injury and she was loaded with clopidogrel $600 \mathrm{mg}$ and aspirin $81 \mathrm{mg}$ and underwent emergent percutaneous coronary angioplasty for $100 \%$ occlusion of the right coronary artery with placement for 3 drugeluting stents. A total of $210 \mathrm{~mL}$ of iodinated contrast with low osmolarity $(884 \mathrm{mOsm} / \mathrm{kg})$ was used. There was no complication during the procedure. Immediately after the procedure, the patient was found to be confused. Head CT without contrast revealed hyperdensity (70 Hounsfield units $[\mathrm{HU}]$ ) along right hemispheric gyri with mild cerebral edema, concerning for subarachnoid hemorrhage (SAH) (figure 1A). The patient was transferred to the intensive care unit at our institution for suspected hemorrhagic stroke. There was no report of seizure activity or acute or chronic renal dysfunction.

On arrival, the patient's blood pressure was $143 / 74 \mathrm{~mm} \mathrm{Hg}$ with a heart rate of $67 \mathrm{bpm}$; other vital signs and laboratory studies were within normal limits. The neurologic examination revealed mild to moderate left hemiparesis, left sensory and visual hemineglect, and right gaze preference. Otherwise, mental status, cranial nerve, sensory, and language examination results were all normal. NIH Stroke Scale score was 10. Examination findings consistent with right middle cerebral artery (MCA) territory syndrome prompted an emergent $\mathrm{CT}$ angiography of head and neck 7 hours after the first CT. There was no vessel occlusion or stenosis involving the MCA, anterior cerebral artery, or internal carotid artery. There was no evidence of cerebral aneurysms, arterial-venous malformations, or vasospasm. The patient received additional iodinated contrast for CT angiography (CTA), but there was no change in the neurologic examination. Notably, the hyperdensity in the sulcal spaces had almost completely resolved on this CTA study (figure 1B). Subsequently, brain MRI without contrast was performed at 17 hours from the first CT scan and showed mild gyral fluid-attenuated

\author{
Correspondence \\ Dr. Harada \\ yharada@uams.edu
}




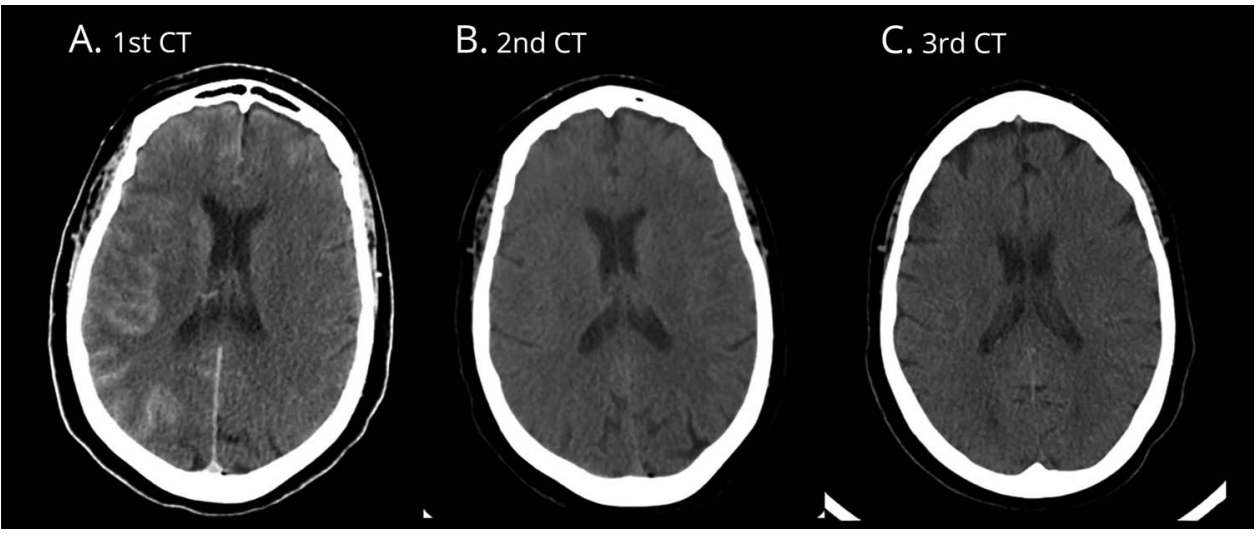

(A) First CT scan after the onset. (B) Seven hours after the first CT scan. (C) Forty hours after first CT scan.

inversion recovery (FLAIR) hyperintensity, which was most pronounced in the right posterior temporal, occipital, posterior frontal, and parietal lobes (figure 2A). Susceptibilityweighted imaging (SWI) did not demonstrate SAH, although the study was limited due to signal artifact in the bilateral frontal lobes (figure 2B), and there was no diffusion restriction, ruling out acute ischemic stroke (figure $2 \mathrm{C}$ ). A 30-minute portable EEG showed mild generalized background slowing without epileptiform discharges. On hospital day 2, the patient's neurologic deficits resolved completely and spontaneously. Repeat CT scan showed resolution of the hemispheric hyperdensity and edema (figure 1, A and C). This presentation seemed most consistent with CIE.

\section{Discussion}

The most common neurologic complications associated with cardiac catherization procedures include acute ischemic stroke secondary to atheroembolism, air embolism, vasospasm, and intimal dissection, with an incidence ranging between $0.05 \%$ and $0.10 \%$ for diagnostic coronary angiography and between $0.12 \%$ and $0.40 \%$ for percutaneous coronary intervention (PCI). ${ }^{1} \mathrm{CIE}$ is rare and a recent systematic review identified only 5 case series and 38 case reports, identifying a total of 52 reported cases between 1970 and $2017 .{ }^{2}$ Neurologic manifestation of CIE varies widely, including visual disturbance in 52\%, focal motor and sensory deficits in $28.8 \%$, encephalopathy in $25 \%$, seizures in $17.3 \%$, global aphasia in $13.5 \%$, and ophthalmoplegia in $3.8 \%$, which can mimic various other disorders. ${ }^{1}$ The details of initial neurologic examination were limited in our case as it was performed at another institution. Neurologic manifestations typically occur within minutes to hours after iodinated contrast agent administration, as was seen in this case. ${ }^{2}$

The current hypothesis for the underlying mechanism of CIE is disruption of the blood-brain barrier ( $\mathrm{BBB}$ ) allowing the contrast agent to permeate into the CNS causing direct neuronal toxicity and cerebral edema. Hyperosmolality of

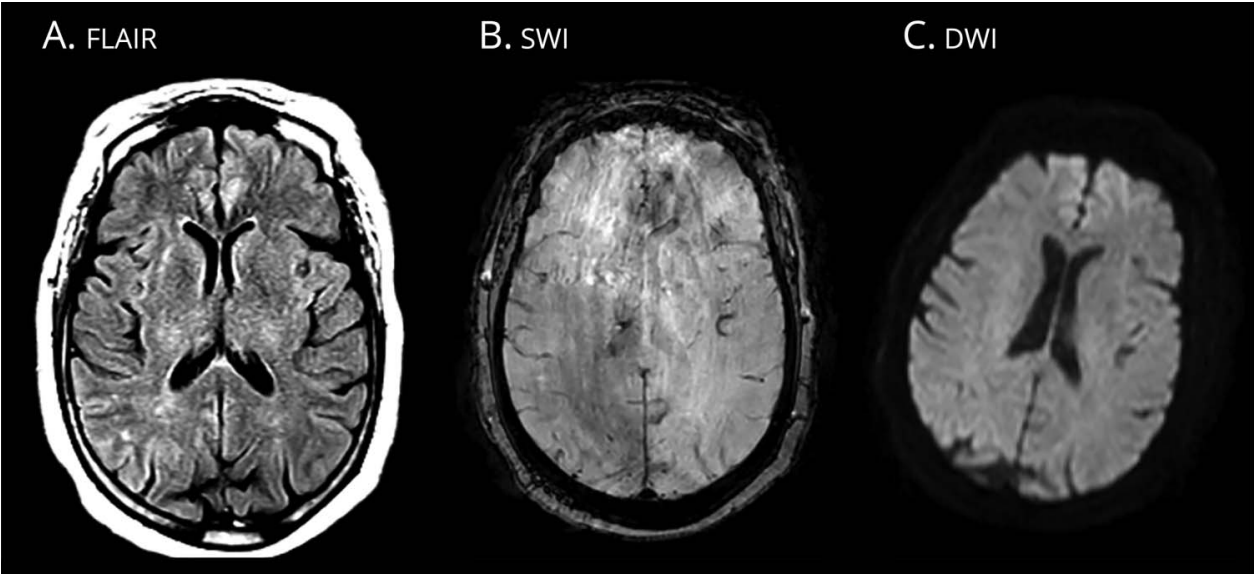

(A) Fluid-attenuated inversion recovery (FLAIR) image 17 hours after first CT scan. (B) Susceptibility-weighted image (SWI) 17 hours after first CT scan. (C) Diffusion-weighted image (DWI) 17 hours after first CT scan. 
contrast media is considered to cause shrinkage of endothelial cells, opening up tight junctions. ${ }^{3}$ Furthermore, contrast agents also have epileptogenic potential and can result in seizures. Underlying chronic hypertension can also lead to $\mathrm{BBB}$ disruption by compromising cerebral autoregulation, which could have been the possible risk factor for CIE in our patient. In addition to the direct contact of contrast with neural tissues, increased neuronal excitability by receptor activation and high lipid solubility of contrast medium are also proposed mechanisms of neuronal injury. ${ }^{2}$ Cortical blindness is a prominent manifestation of CIE, which has been attributed to the relatively higher permeability of the $\mathrm{BBB}$ in the occipital cortex. ${ }^{2,4}$

Although controversial, there is a reported correlation beLiterature reports that $200 \mathrm{~mL}$ of iodine contrast is the maximum recommended dose to prevent toxicity. ${ }^{6}$ The median volume of contrast medium used for cardiac catheterization in the 52 patients who developed CIE was $252 \mathrm{~mL}$ and ranged widely from 75 to $1,500 \mathrm{~mL}$. $^{1}$ Low osmolar agents may be associated with increased risk of CIE. ${ }^{2}$ Our patient received low osmolarity agents, which could have contributed to the development of CIE.

Head CT results may mimic SAH, as was seen in our case, because of hyperdensity in the subarachnoid space due to iodinated contrast extravasation. CT may also show combination of poorly localized cortical and subcortical enhancement and cerebral edema. Although it did not help differentiation in our case, the density of the lesion on the Hounsfield scale can be useful in distinguishing CIE from SAH when it is high. Blood has a density ranging between 40 and $60 \mathrm{HU}$ and contrast media have higher attenuation values, usually between 50 and $1,000 \mathrm{HU}^{2,7}$ As was seen in our case, the temporal evolution of subarachnoid hyperdensity seen on serial CT scans may help differentiate CIE from SAH. CIE-related subarachnoid hyperdensity resolves within 12-24 hours, whereas $85 \%-93 \%$ of SAH cases continue to show hyperdensity beyond 2 days after onset. $^{8}$ In our patient, the hyperdensity completely resolved by hospital day 2. On MRI, an increased FLAIR signal abnormality along the gyri can be seen in both SAH and CIE. In our case, the normal SWI scan argued for the latter. In order to further differentiate SAH from CIE, lumbar puncture may be helpful. Whereas SAH may show the presence of xanthochromia and red blood cells, CIE will not. Simultaneous measurement of iodinated contrast concentration in CSF and serum have been reported to be useful. ${ }^{9}$ These laboratory tests as well as vessel study such as conventional angiogram were not performed in our patient, given clinical and radiologic improvement by the next day.

Our case mimicked acute right MCA syndrome due to the neurologic examination showing left-sided hemiplegia, sensory and visual extinction, and right gaze preference. Similarly, Chisci et al. ${ }^{6}$ reported a case of CIE that presented with transient acute onset global aphasia and right hemiparesis lasting tween the iodinated contrast dose and incidence of CIE. ${ }^{5}$

for 24 hours, mimicking a left MCA syndrome, after PCI and left carotid artery stenting procedure. Brain MRI may help differentiate CIE from acute ischemic stroke because diffusionweighted imaging (DWI) and apparent diffusion coefficient sequences provide a quantitative measure of water diffusion, and decreased water diffusion is seen with cytotoxic edema and most commonly with acute ischemic stroke, among other rarer conditions. Whereas FLAIR hyperintensity in the absence of DWI changes can be seen in various disorders causing vasogenic edema such as posterior reversible encephalopathy, our case was most consistent with CIE given the clinical context where symptoms occurred immediately after contrast administration. The unilateral involvement of CIE, as seen in our case, has been reported and was attributed to the position of the angiography catheter among other factors. The reason for unilaterality in our case remains unclear.

Prognosis of CIE is typically favorable with complete resolution of symptoms within 24-72 hours after contrast administration, except for some reported cases where ophthalmoplegia resolved after 10 days. ${ }^{5}$ Junck and Marshall ${ }^{10}$ reported that reversibility of the toxicity depends on $\mathrm{BBB}$ reconstitution and the rate of clearance of the offending agent.

We report a rare case of CIE following cardiac catheterization that mimicked a right MCA syndrome clinically and SAH radiologically, creating a diagnostic dilemma. Timely recognition of this rare complication associated with cardiac catheterization, close neurologic monitoring, and watchful management helped avoid unnecessary invasive procedures such as lumbar puncture and cerebral angiogram and helped reduce hospital length of stay. We emphasize the importance of awareness of this rare neurologic complication following contrast administration.

\section{Study funding}

No targeted funding reported.

\section{Disclosure}

The authors report no relevant disclosures. Go to Neurology. org/ $\mathrm{N}$ for full disclosures.

Appendix Authors

\begin{tabular}{lll}
\hline Name & Location & Contribution \\
\hline $\begin{array}{l}\text { Yohei Harada, } \\
\text { MD }\end{array}$ & $\begin{array}{l}\text { University of } \\
\text { Arkansas for Medical } \\
\text { Sciences, Little Rock }\end{array}$ & $\begin{array}{l}\text { Cared for the patient } \\
\text { presented, wrote the text, } \\
\text { assembled the figures }\end{array}$ \\
$\begin{array}{l}\text { Supriya R. } \\
\text { Kairamkonda, } \\
\text { MD }\end{array}$ & $\begin{array}{l}\text { University of } \\
\text { Arkansas for Medical } \\
\text { Sciences, Little Rock }\end{array}$ & $\begin{array}{l}\text { Cared for the patient } \\
\text { presented, wrote the text }\end{array}$ \\
$\begin{array}{l}\text { Ushna Ilyas, } \\
\text { MD }\end{array}$ & $\begin{array}{l}\text { University of } \\
\text { Arkansas for Medical } \\
\text { Sciences, Little Rock }\end{array}$ & $\begin{array}{l}\text { Cared for the patient } \\
\text { presented, wrote the text }\end{array}$ \\
\hline $\begin{array}{l}\text { Naga V.K. } \\
\text { Pothineni, MD }\end{array}$ & $\begin{array}{l}\text { University of } \\
\text { Arkansas for Medical } \\
\text { Sciences, Little Rock }\end{array}$ & $\begin{array}{l}\text { Cared for the patient } \\
\text { presented, supervised } \\
\text { drafting/revision of the } \\
\text { manuscript }\end{array}$ \\
& $\begin{array}{l}\text { mont } \\
\end{array}$ &
\end{tabular}


Appendix (continued)

\begin{tabular}{lll}
\hline Name & Location & Contribution \\
\hline $\begin{array}{l}\text { Rohan S. } \\
\text { Samant, MD }\end{array}$ & $\begin{array}{l}\text { University of } \\
\text { Arkansas for Medical } \\
\text { Sciences, Little Rock }\end{array}$ & $\begin{array}{l}\text { Cared for the patient } \\
\text { presented, assembled figures }\end{array}$ \\
\hline $\begin{array}{l}\text { Vishank A. } \\
\text { Shah, MD }\end{array}$ & $\begin{array}{l}\text { University of } \\
\text { Arkansas for Medical } \\
\text { Sciences, Little Rock }\end{array}$ & $\begin{array}{l}\text { Cared for the patient } \\
\text { presented, supervised } \\
\text { drafting/revision of the } \\
\text { manuscript }\end{array}$ \\
\hline $\begin{array}{l}\text { Nidhi Kapoor, } \\
\text { MD }\end{array}$ & $\begin{array}{l}\text { University of } \\
\text { Arkansas for Medical } \\
\text { Sciences, Little Rock }\end{array}$ & $\begin{array}{l}\text { Cared for the patient } \\
\text { presented, supervised } \\
\text { drafting/revision of the } \\
\text { manuscript }\end{array}$ \\
\hline $\begin{array}{l}\text { Sanjeeva } \\
\text { Onteddu, MD }\end{array}$ & $\begin{array}{l}\text { University of } \\
\text { Arkansas for Medical } \\
\text { Sciences, Little Rock }\end{array}$ & $\begin{array}{l}\text { Cared for the patient } \\
\text { presented, supervised } \\
\text { drafting/revision of the } \\
\text { manuscript }\end{array}$ \\
\hline $\begin{array}{l}\text { Krishna } \\
\text { Nalleballe, MD }\end{array}$ & $\begin{array}{l}\text { University of } \\
\text { Arkansas for Medical } \\
\text { Sciences, Little Rock }\end{array}$ & $\begin{array}{l}\text { Cared for the patient } \\
\text { presented, supervised } \\
\text { revision, concept/design of } \\
\text { the manuscript }\end{array}$ \\
\hline
\end{tabular}

\section{References}

1. Spina R, Simon N, Markus R, Muller DW, Kathir K. Recurrent contrast-induced encephalopathy following coronary angiography. Intern Med J 2017;47: 221-224.

2. Spina R, Simon N, Markus R, Muller DW, Kathir K. Contrast-induced encephalopathy following cardiac catheterization. Catheter Cardiovasc Interv 2017;90: 257-268.

3. Leong S, Fanning NF. Persistent neurological deficit from iodinated contrast encephalopathy following intracranial aneurysm coiling: a case report and review of the literature. Interv Neuroradiol 2012;18:33-41.

4. Park JC, Ahn JH, Chang IB, Oh JK, Kim JH, Song JH. A case of unusual presentation of contrast-induced encephalopathy after cerebral angiography using iodixanol. J Cerebrovasc Endovasc Neurosurg 2017;19:184-188.

5. Kocabay G, Karabay CY, Kalayci A, et al. Contrast-induced neurotoxicity after coronary angiography. Herz 2014;39:522-527.

6. Chisci E, Setacci F, de Donato G, Setacci C. A case of contrast-induced encephalopathy using iodixanol. J Endovasc Ther 2011;18:540-544.

7. Schulte-Altedorneburg G, Rub K, Scheglmann K. Simultaneous ischemic and neurotoxic brain damage after coronary angiography. Neurol Res 2004;26: $79-82$.

8. Carpenter CR, Hussain AM, Ward MJ, et al. Spontaneous subarachnoid hemorrhage: a systematic review and meta-analysis describing the diagnostic accuracy of history, physical examination, imaging, and lumbar puncture with an exploration of tes thresholds. Acad Emerg Med 2016;23:963-1003.

9. Velden J, Milz P, Winkler F, Seelos K, Hamann GF. Nonionic contrast neurotoxicity after coronary angiography mimicking subarachnoid hemorrhage. Eur Neurol 2003; 49:249-251.

10. Junck L, Marshall WH. Neurotoxicity of radiological contrast agents. Ann Neurol 1983;13:469-484. 


\section{Neurology}

\section{Pearls \& Oy-sters: Contrast-induced encephalopathy following coronary angiography: A rare stroke mimic}

Yohei Harada, Supriya R. Kairamkonda, Ushna Ilyas, et al. Neurology 2020;94;e2491-e2494 Published Online before print May 7, 2020

DOI 10.1212/WNL.0000000000009590

\section{This information is current as of May 7, 2020}

\section{Updated Information \&} Services

\section{References}

Subspecialty Collections

Permissions \& Licensing

Reprints including high resolution figures, can be found at: http://n.neurology.org/content/94/23/e2491.full

This article cites 10 articles, 0 of which you can access for free at: http://n.neurology.org/content/94/23/e2491.full\#ref-list-1

This article, along with others on similar topics, appears in the following collection(s):

\section{Encephalitis}

http://n.neurology.org/cgi/collection/encephalitis

Other cerebrovascular disease/ Stroke

http://n.neurology.org/cgi/collection/other_cerebrovascular_disease_s troke

Information about reproducing this article in parts (figures,tables) or in its entirety can be found online at:

http://www.neurology.org/about/about_the_journal\#permissions

Information about ordering reprints can be found online:

http://n.neurology.org/subscribers/advertise

Neurology ${ }^{\circledR}$ is the official journal of the American Academy of Neurology. Published continuously since 1951, it is now a weekly with 48 issues per year. Copyright @ 2020 American Academy of Neurology. All rights reserved. Print ISSN: 0028-3878. Online ISSN: 1526-632X.

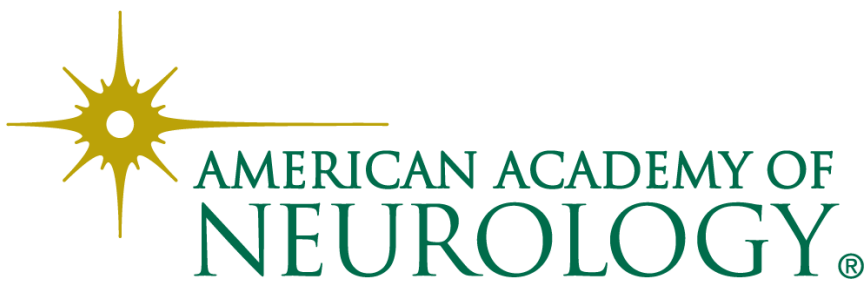

